\title{
DILEMMA IN LABORATORY DIAGNOSIS OF DENGUE, CHIKUNGUNYA AND ZIKA VIRUSES
}

\author{
MUSHTAQUE AHMED, NABEELA MAHBOOB, KAZI TAIB MAMUN, HASINA IQBAL
}

\begin{abstract}
Dengue, Chikungunya and Zika are the vector-borne diseases that constitute a potential epidemiological risk due to the recent increase in cases, complications, and severity. The co-circulation of the three diseases is a matter of public health interest due to their transmission by the same vector as well as the increase in the number of cases of severe dengue hemorrhagic fever, post-chikungunya chronic joint disease and microcephaly related to Zika virus. Therefore, it is important to be familiar with the various clinical presentations and laboratory methods to make the differential diagnosis, start appropriate treatment, and prevent the associated complications.
\end{abstract}

Keywords: Dengue, Chikungunya, Zika

Received: 23 December 2018

Accepted: 11 April 2019

DOI: https://doi.org/10.3329/ bjmed.v30i2.41535

\section{Introduction:}

Arthropod-borne virus infections, including Dengue, Chikungunya and Zika viruses are rising globally, facilitated by increased urbanization and International travel. ${ }^{1}$ Dengue virus (DENV) and Chikungunya virus (CHIKV) are already established in most tropical regions, while Zika virus (ZIKV) is rapidly spreading throughout Central and South America. ZIKV, like DENV, is an emerging mosquito-borne member of the Flaviviridae Family. ${ }^{2}$ Since 2000 dengue fever cases are occurring in Bangladesh, with very few mortality reports. Most of the dengue cases are reported in June as intermittent rains and high temperature and humidity during the month create the ideal breeding conditions for Aedes mosquitoes. However this year, 2018 dengue cases have been reported in Dhaka city from April. ${ }^{3}$ According to Directorate General of Health Services (DGHS) thousands of dengue cases with many death have been reported so far this year in Dhaka. ${ }^{4}$ The first recognized outbreak of chikungunya was reported in 2008 in two villages in the northwest part of the country adjacent to Indian border In Bangladesh,. Later two small outbreaks were documented in rural communities in 2011 and 2012. However, a major outbreak of chikungunya virus occurred for the first time in Dhaka, Bangladesh between May and September 2017. ${ }^{5}$ The Bangladeshi Ministry of Health reported 984 cases confirmed by real-time PCR assay and more than 13176 clinically confirmed cases in 17 of 64 districts during this period. ${ }^{6}$ Bangladesh confirmed its first case of the Zika virus in 2016 from the serum collected from febrile patients of on-going dengue surveillance conducted in three selected districts of Bangladesh during 20132016. Outbreak of Zika virus in Bangladesh is of serious concern owing to its association with congenital anomalies/neurological-manifestations. ${ }^{7}$

Infections with Dengue, Chikungunya and Zika viruses yield similar overlapping symptoms, including fever, rash, and joint pain which complicates the differential diagnosis. ${ }^{8}$ Serological tests are an important method for diagnosing acute infections as well as for disease surveillance. Enzyme linked immunosorbent assay (ELISA) and indirect immunofluorescence test (IIFT) systems based on optimized antigens enable sensitive and specific detection of anti- DENV, CHIKV and ZIKV antibodies in patient serum or plasma samples. ${ }^{9}$ Diagnosis and the serotype of the viruses can be determined using the reverse transcription polymerase chain reaction (RT-PCR). ${ }^{10}$ There is currently no

1. Professor, Department of Microbiology, Popular Medical College, Dhaka.

2. Assistant Professor (cc), Department of Microbiology, Popular Medical College, Dhaka.

3. Research Investigator, icddrb.

4. Associate Professor (cc), Department of Microbiology, Popular Medical College, Dhaka.

Address of Correspondence: Dr. Nabeela Mahboob, Assistant Professor (cc), Department of Microbiology, Popular Medical College, Dhaka. Email: nabeela.islam311@gmail.com Contact no.: 01769050442, 01717063420

Bangladesh J Medicine 2019; 30 : 83-92 
licensed Dengue, Chikungunya and Zika vaccine available and the only means of prevention is through surveillance and vector control. There is also no effective anti-viral therapeutic on the market and supportive therapy such as fluid replacement is the only treatment for severe forms of the disease. Therefore, an early and accurate laboratory diagnosis of flaviviruses could assist in clinical management. ${ }^{11}$

\section{Disease Overview:}

All three viruses are mainly transmitted by the same vectors, Aedes aegypti and Aedes albopictus. ${ }^{12}$ Infections with these viruses are often asymptomatic; the initial clinical presentation is non-specific and symptoms such as fever, maculopapular rash, musculoskeletal pain, headache and conjunctivitis can be seen with any of these viruses. ${ }^{13}$ Although in most cases the disease is mild but they have been linked to complications such as ZIKV infection with congenital malformations, in particular microcephaly, and neurological condition, Guillain-Barré syndrome. ${ }^{14}$ CHIKV can result in a severe chronic arthralgia and/ or arthritis that can last months to years following the initial infection. ${ }^{15,16}$ In a small proportion of cases, DENV infections develop into the life-threatening dengue hemorrhagic fever or dengue shock syndrome. ${ }^{17}$

\section{Diagnostic Methods:}

Assay selection depends both on the timing of sample collection and the purpose of testing. In the acute phase of infection, assays that detect the virus directly by viral isolation, viral RNA or viral antigen perform best. In the convalescent phase of infection, serological assays that detect the host antibody response (IgM, IgG and IgA antibodies) can be used, though paired acute and convalescent samples are used to diagnose/ distinguish current from past infections. ${ }^{18}$ The laboratory diagnosis for arboviruses has long relied on serological methods which can be challenging. ${ }^{19,20}$ Neutralization assays are useful but cannot always yield a definitive diagnosis. ${ }^{21}$ However, if blood and urine samples are obtained early in the illness, a firm diagnosis can be established by specific detection using molecular methods. ${ }^{22}$

\section{(1) Virus Isolation:}

Virus isolation is very labor-intensive and costly but is more specific than antibody detection using serologic methods. ${ }^{23}$ Viral culture may detect virus in the first 3 days of illness; however, it should be handled under biosafety level (BSL) 3 conditions. ${ }^{24}$ Isolation of DENV or CHIKV can be performed via mosquito inoculation or cell culture method. Mosquito inoculation is the most sensitive isolation method but is impractical for routine diagnosis due to the highly specialized requirements and high maintenance costs. ${ }^{25} \mathrm{CHIKV}$ isolation can also be performed by intracerebral inoculation of mice. ${ }^{26}$ Cell culture is in wider use, with preference given to the mosquito cell line $\mathrm{C} 6 / 36$ (cloned from $A$. albopictus) or AP61 (cloned from $A$. pseudoscutellaris). ${ }^{23,26}$ Other less sensitive options include mammalian cell cultures such as Vero, LLCMK2, and BHK-21. The resultant virus isolate may be further characterized by subsequent in vitro studies, such as genome sequencing, virus neutralization, and infection studies. ${ }^{25}$ Virus isolation is highly specific and has a theoretical detection limit of a single viable virus, although, in practice, the sensitivity is only approximately $40.5 \%$ in cell line-based virus isolation. It also requires highly trained operators, a dependence on sample integrity. A short viremia period from illness onset provides a narrow window of opportunity for diagnosis by culture. Virus isolation followed by an immunofluorescence assay for confirmation requires days to weeks. Therefore, despite its advantages, this approach is not widely used in routine diagnostic laboratories and may be of more use in surveillance purposes. ${ }^{23,26}$ There are reports describing the Zika infection of various primary cells or immortalized cell lines. Moreover, ZIKV was shown to replicate in various human cell types like skin cells and lung epithelial cells. The Aedes C6/36 cells were also infected, this was also described for other related viruses. Furthermore, Himmelsbach et al. observed that a lot of human and animal cell lines (A549, COS7, HepG2/ C3A, Huh7.5, HaCaT, N29.1, SH-SY5Y, Vero and 293T cells) were susceptible to ZIKV infection. ${ }^{27}$

\section{(2) Nucleic acid detection:}

Detection of viral nucleic acid can be accomplished by reverse transcriptase polymerase chain reaction (RTPCR) or isothermal amplification methods.

\subsection{Polymerase chain reaction (RT-PCR)}

Virus nucleic acid detection by RT-PCR is only effective during the viraemic phase i.e., within the first week of clinical symptoms onset. ${ }^{28}$ There is a wide variety of specimen types that can be tested with RT-PCR. Serum and/or plasma can be used for diagnosis of DENV, CHIKV and ZIKV. For DENV, urine and saliva have been found to be suitable specimen types as well. ${ }^{29}$ It has also been shown that for detection of Zika virus urine can be the ideal sample type. ${ }^{30}$

Dengue fever can be diagnosed by direct detection of dengue virus, e.g. by PCR only during the viraemic phase of dengue infection when initial symptoms arise (approx. 0 to 5 days after onset of symptoms). ${ }^{31}$ Current tests are between $80-90 \%$ sensitive, and more that $95 \%$ 
specific. PCR can be used to determine which of the 4 serotypes dengue is causing the infection. ${ }^{32}$ Chikungunya infections cause high levels of viremia which typically last for 4-6 days after the onset of illness. ${ }^{33}$ RT-PCR can therefore be done within the first 7 days from an acute-phase specimen to confirm chikungunya virus infection. ${ }^{34}$ The sensitivity for CHIKV in the early stages of infection is $88.3 \% .^{24} \mathrm{RT}-$ PCR products may also be used for genotyping of the virus, allowing comparisons with virus samples from various geographical sources. ${ }^{35}$ In case of Zika this is the test of choice due to its high sensitivity and specificity, which in some studies are as high as 100\% for both. In areas of active Zika virus transmission, the Centers for Disease Control and Prevention (CDC) guidelines propose that pregnant women with Zika symptoms should be analysed with RT-PCR. If the results are positive or inconclusive, repeated foetal ultrasounds and PCR in amniotic fluid must be performed throughout the pregnancy. If the results are negative, an ultrasound must be performed to look for microcephaly or intracranial calcifications. ${ }^{36,37}$

In response to the diagnostic challenges presented by these viruses, the CDC developed the Trioplex realtime reverse transcriptase-polymerase chain reaction assay (Trioplex assay) for the concurrent detection of DENV, CHIKV and ZIKV RNA in human serum, plasma and cerebrospinal fluid (CSF). ${ }^{38}$ Simultaneous testing of more than one specimen type from each patient provides a $6.4 \%$ additional diagnostic sensitivity. ${ }^{39}$

\subsection{Isothermal amplification method:}

Reverse transcription-loop mediated isothermal amplification (RT-LAMP) has emerged for viral detection due to simplified thermal management and high sensitivity and specificity towards targeted sequences. ${ }^{40}$ Song et al. and Santiago et al. demonstrated RT-LAMP as an effective method for rapid detection of Dengue, Chikungunya and Zika viruses. ${ }^{41-43}$

\section{(3) Viral antigen detection:}

Nonstructural protein 1 (NS1) antigen is a highly conserved glycoprotein produced during the virus replication process. The NS1 glycoprotein is produced by all flaviviruses. ${ }^{44,45}$ Several commercial assays, consisting of both rapid tests and enzyme-linked immunosorbent assay (ELISA) kits, are available for the detection of the NS1 antigen. Kumar et al. and Chakraverti et al. found no significant difference in sensitivity and specificity between ICT and ELISA tests for detection of dengue infection. ${ }^{46,47}$ Serum is the most common sample type. In DENV infections the Dengue Virus NS1 ELISA is an important early screening test, which is possible from day 1 to approximately day 18 after onset of symptoms that helps to minimize the diagnostic gap between RT-PCR and antibody positivity. ${ }^{24}$ This technique reportedly has a sensitivity of $80-100 \%$ and a specificity of $100 \%$. An antigenbased commercial detection assay is not widely available for CHIKV, ZIKV. The ones described by Chen et al. and Bosch et al. could not gain popularity as the test performance was poor. ${ }^{48,49}$

\section{(4) Serological diagnosis:}

Serological tests provide a much longer window for diagnostics than direct detection methods.

\subsection{Antibody detection:}

Antibodies against DENV, CHIKV and ZIKV appear around 4 to 7 days after symptom onset. ${ }^{50}$ The immune response varies depending on whether the individual has a primary or secondary flavivirus infection. ${ }^{24}$ Antibody response to infection differs according to the immune status of the host. ${ }^{10}$ When flavivirus infection occurs in persons who have not previously been infected with a flavivirus or immunized with a flavivirus vaccine (e.g. for yellow fever, Japanese encephalitis, tick-borne encephalitis), the patients develop a primary antibody response characterized by a slow increase of specific antibodies. IgM antibodies are the first immunoglobulin isotype to appear. These antibodies are detectable in $50 \%$ of patients by day 3 of illness, increasing to $80 \%$ by day 5 and $99 \%$ by day $10 .{ }^{23} \mathrm{IgM}$ levels peak about two weeks after the onset of symptoms and then decline generally to undetectable levels over 2-3 months. IgG is generally detectable at low titres at the end of the first week of illness, increasing slowly thereafter, with serum IgG still detectable after several months, and probably even for life. ${ }^{25,51}$ During a secondary infection, antibody titres rise rapidly and react broadly against many flaviviruses. The dominant immunoglobulin isotype is IgG which is detectable at high levels, even in the acute phase, and persists for periods lasting from 10 months to life. Early convalescent stage IgM levels are significantly lower in secondary infections than in primary ones and may be undetectable in some cases, depending on the test used. ${ }^{52}$

The following table summarizes results that may be seen with antibody testing. 
Table-I

Antibody testing results with interpretation

\begin{tabular}{lll}
\hline IgM Result & IgG Result & Possible Interpretation \\
\hline Positive & Negative & Recent infection \\
Positive & Positive & Recent infection \\
Low or negative or & Four-fold increase in & Recent infection \\
not tested & samples taken 2-4 weeks apart & \\
Low or negative & Positive & Past infection \\
Negative & Negative & $\begin{array}{l}\text { Too soon after initial exposure for antibodies to } \\
\text { develop or symptoms due to another cause. }\end{array}$ \\
\hline
\end{tabular}

There are several commercial assays available for the detection of the flavivirus antibody consisting of Immunochromatographic test (ICT), Enzyme-linked immunosorbent assay (ELISA), Immunofluorescence tests, Haemagglutination tests.

\subsection{1: Immunochromatographic test (ICT):} Relatively inexpensive serological tests, and in particular rapid point-of-care device, have become more widely used in endemic settings. Although not as sensitive as PCR or ELISA, ICT is quick and require only a minimum of technical expertise to perform. ${ }^{11}$ ICT for IgM and IgG are routinely used in clinical laboratories for the rapid diagnosis of dengue and can differentiate between primary and secondary infections. Rapid CHIKV IgM tests are now available, but little information exists regarding their performance. The sensitivity of these tests evaluated by Burdino et al. in settings with a high prevalence of CHIKV infection is poor (range 1.9\%-50.8\%) compared with that for reference assays, especially in the acute phase of disease. ${ }^{53}$ Recently, Rapid Diagnostic Test (RDT) kit for detecting IgG/IgM antibodies against Zika virus (Zika IgG/IgM RDT kit) has been developed by Kim et al. and proved to be effective in the field. The diagnostic accuracy of Zika RDT was fairly high; sensitivity and specificity for IgG was 99.0 and $99.3 \%$, respectively, while for IgM it was 96.7 and $98.7 \%$, respectively. The Zika RDT kit is very simple to use, rapid to assay, and very sensitive and highly specific. Therefore, it would serve as a choice of method for point-of-care diagnosis and large scale surveys of ZIKV infection among people under clinical or field conditions worldwide in endemic areas. ${ }^{54}$

\subsection{2: Enzyme-linked immunosorbent assay} (ELISA): MAC-ELISA has become an important tool for routine diagnosis. Different formats such as capture ELISA, capture ultramicro ELISA, dot-ELISA, AuBioDOT IgM capture and dipsticks have been developed. MAC-ELISA has a sensitivity and specificity of approximately $90 \%$ and $98 \%$, respectively but only when used five or more days after onset of fever (i.e., in convalescent phase). ${ }^{24}$ Detection of anti-dengue IgM antibodies (MAC-ELISA) is the serological test of choice. It is not possible to detect serotypes of the virus with these tests. ${ }^{55} \mathrm{CHIKV}$ IgM can be detected by CHIKV IgM antibody capture enzyme-linked immunosorbent assays (MAC-ELISAs). ${ }^{56}$ Detection of IgM through the ELISA technique may be used for CHIKV from 4 days after the onset of fever to 2 months. A sensitivity of $81.8 \%$ was reported by Chen et al. for late stages of the disease. IgG may be detected in samples in the convalescence stage and persist throughout life. ${ }^{43}$ To diagnose ZIKV, detection of IgM by ELISA may be used in the convalescence phase (after 6 days after onset of symptoms). ${ }^{24}$ Zika virus-specific IgM levels are variable, but generally are positive starting near day 4 after onset of symptoms and continuing for up to 12 weeks post symptom onset or exposure, but may persist longer. For non-pregnant symptomatic individuals with possible exposure to Zika virus, nucleic acid testing (NAT) in serum and urine and Zika virus and/or dengue virus IgM testing of serum should be performed. Zika virus and dengue virus IgM serology testing should be performed on NAT negative samples collected $<14$ days after onset of symptoms or on samples collected e"14 days after onset of symptoms. NAT testing is not recommended on specimens collected e" 14 days after symptom onset. For zika virus infected symptomatic pregnant women, IgM serology is performed concurrently with NAT as soon as possible, up to 12 weeks after symptom onset. IgM serology testing is not routinely recommended for asymptomatic pregnant women with ongoing possible Zika virus exposure (i.e., residence in or frequent travel to an area with risk of Zika). Here, NAT testing is recommended three times during pregnancy. Asymptomatic pregnant women with recent possible exposure to Zika virus but no ongoing exposure (i.e., travelers) may be considered for testing. Although testing is not routinely 
recommended, but if testing is performed, the same algorithm as for symptomatic pregnant women should be followed using the timeframe from the last possible exposure to Zika virus. ${ }^{57}$

Serological methods are useful for studying the longterm consequences of infection. For example, if the link between ZIKV infection and congenital malformations is confirmed, ZIKV serology could play an important future role in prenatal diagnostics. ${ }^{58}$ Serology is also useful for screening donated blood, especially in travelers returning from DENV, CHIKV and ZIKV endemic regions to non affected countries. ${ }^{23}$ A further, critical role for serological studies is to monitor the growing epidemiological reach of flavivirus. As ZIKV, DENV and CHIKV are expected to continue to spread around the globe, knowledge about emerging endemic regions is valuable for providing effective patient diagnostics. ${ }^{50}$

To distinguish primary from secondary dengue virus infections a dengue virus E/M protein-specific IgM/ IgG ratio can be used. IgM capture and IgG capture ELISAs are the most common assays for this purpose. Falconar et al defined Dengue infection as primary if the IgM/IgG OD ratio is greater than 1.2 (using patient's sera at $1 / 100$ dilution) or 1.4 (using patient's sera at $1 / 20$ dilutions). The infection is secondary if the ratio is less than 1.2 or 1.4 . However, ratios may vary between laboratories, thus indicating the need for better standardization of test performance. ${ }^{59}$

Positive detection for serum anti-dengue IgA capture ELISA (AAC-ELISA) often occurs one day after that for IgM. Studies by Vázquez et al. and Nawa demonstrated that the IgA titre peaks around day 8 after onset of fever and decreases rapidly until it is undetectable by day 40. No differences in IgA titres were found between patients with primary or secondary infections. Even though IgA values are generally lower than IgM, both in serum and saliva, the two methods could be performed together to help in interpreting dengue serology. ${ }^{60,61}$ This approach is not used very often and requires additional evaluation.

4.1.3: Immunofluorescence assays: Immunofluorescence assays are sensitive and specific but lack the ability to quantify antibodies, are thus subjective. Antibody detection by indirect immunofluorescence test (IIFT) is based on cells infected with the corresponding virus, which provide highly sensitive diagnostics. Positive and negative results are evaluated by fluorescence microscopy. ${ }^{62}$ In clinically characterized samples the IIFT also had high performance (96\% accuracy), but a technician skilled in immunofluorescence assay techniques is required. ${ }^{57}$

4.1.4: Haemagglutination-inhibition tests: Clinical symptoms along with a fourfold Haemagglutination Inhibition (HI) antibody difference in paired serum samples indicate flavivirus infection. ${ }^{63}$ The assay does not discriminate between infections by closely related flaviviruses (e.g. between dengue virus and Japanese encephalitis virus or West Nile virus) nor between immunoglobulin isotypes. The response to a primary infection is characterized by the low level of antibodies in the acute-phase serum drawn before day 5 and a slow elevation of HI antibody titre thereafter. During secondary dengue infections $\mathrm{HI}$ antibody titre rises rapidly, usually exceeding $1: 1280$. Values below this are generally observed in convalescent sera from patients with primary responses. ${ }^{23}$

\section{(5) Plaque reduction neutralization tests (PRNT):}

Plaque reduction neutralization tests (PRNT) are very useful because they are quite specific and gold standard for confirmation of serologic test results. Plaque reduction neutralization test may help in determining false positive IgM results. Almost 90\% samples are positive by plaque reduction neutralization test out of all MAC-ELISA positive cases. A sample with positive or equivocal MAC-ELISA results with a neutralizing titer is classified as a confirmed virus positive sample; those with negative results of plaque reduction neutralization testing are considered to have nonspecific reactivity (i.e., to be negative for virus). ${ }^{57}$ Due to cross-reaction with other flaviviruses and possible nonspecific reactivity, results of MAC-ELISA may be difficult to interpret. Consequently, presumed positive, equivocal, or inconclusive tests must be forwarded for confirmation by plaque-reduction neutralization testing (PRNT). ${ }^{58}$ The major drawback to PRNT is that it requires the use of live virus. The test must be carried out in BSL-3 that requires special laboratory containment equipments. ${ }^{63}$

(6) Matrix assisted laser desorption ionization-time of flight mass spectrometry (MALDI-TOF MS):

Matrix assisted laser desorption ionization-time of flight mass spectrometry (MALDI-TOF MS) has emerged as a potential tool for microbial identification and diagnosis. The process is rapid, sensitive, and economical in terms of both labor and costs involved. The limitation of the technology is that identification of new isolates is possible only if the spectral database contains peptide mass fingerprints of the type strains of specific genera/species/subspecies/strains. ${ }^{64}$ Among these three viruses, only Type 1 dengue virus can be detected by MALDI-TOF MS revealed by a study performed by Chen et al. ${ }^{65}$ 


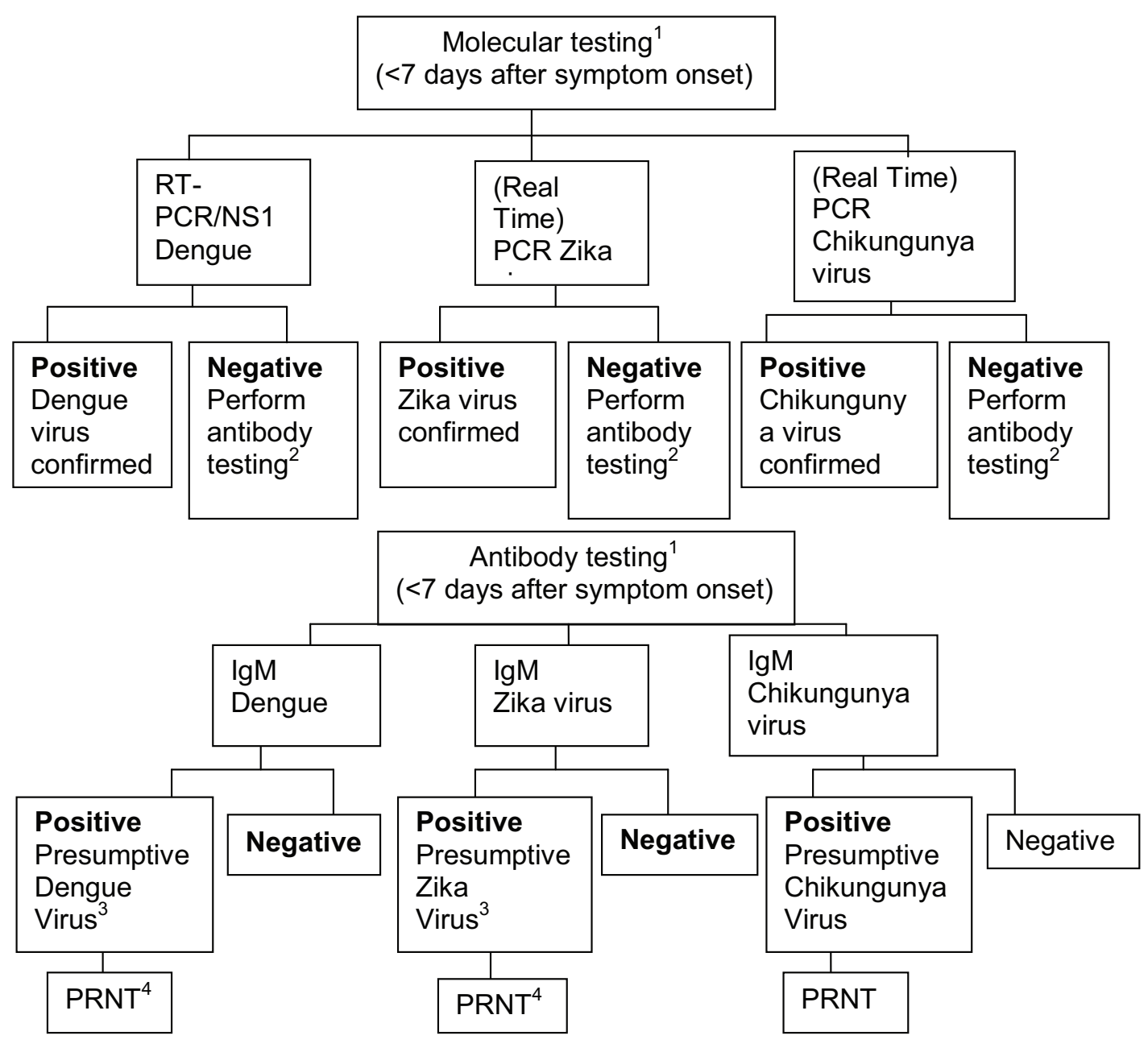

Figure-1. Tiered algorithm for arbovirus detection for suspected causes of Dengue Chikungunya or Zika (only performed if patient symptomatic and travel history indicates travel to affected area) ${ }^{\mathbf{6}}$

${ }^{1}$ Due to extensive cross-reactivity in flavivirus serological assays, for samples collected $<7$ days of illness onset, molecular detection should be performed first. ${ }^{2}$ Perform if samples $>4$ days after symptom onset. ${ }^{3}$ Extensive cross-reactivity would be expected in samples from DENV/ZIKV circulation areas. A positive IgM assay with either antigen should be confirmed by using PRNT against ZIKV and DENV as well as any other flavivirus that might be found in that geographic area (including travel areas). ${ }^{4}$ PRNT should include any flavivirus that might be found in that geographic area (including travel areas).

The Laboratory diagnosis Dengue, Chikungunya and Zika is challenging, as well as confusing. The gold standard for diagnosis of Dengue, Chikungunya and Zika in a febrile patient is obviously the specific virus detection, virus isolation and virus identification after by cell culture. However, this is gradually being replaced by real time reverse transcriptase polymerase chain reaction (RT-PCR) method for more rapid diagnosis ${ }^{67}$ However, the tests are almost impractical in most places because of requirement of specialized laboratory facilities and are also laborious. They are feasible only in rare centers of national importance, and hence in most or almost all laboratory serological methods are being performed. ${ }^{68}$ Serological diagnosis is a most challenging matter due to its cross-reactivity to homologous and heterologous flavivirus antigens. However, great advances are achieved in analyzing the methods that target different structural and nonstructural proteins for serodiagnosis. Of these, the NS1, IgM, IgG detection by ICT and ELISA is the most favored one because of the ease and rapidity of the test. Thus, while the Rapid test can be more feasible in small peripheral laboratories and in field situations, in wellestablished laboratories, the concomitant performance of the Rapid test, with confirmation by the ELISA on those samples, ensures both rapidity as well as quality of reported results. ${ }^{67}$ Whichever the test, the complexity 
of Dengue, Chikungunya and Zika virus diagnosis cannot be disregarded, showing thereby that a single assay alone cannot be totally relied upon. Thus, a diagnosis of a particular virus should always be made taking into account the clinical presentation of the patient, the performance characteristics of the serological test employed and the knowledge of the virus circulating in that particular geographical region.

\section{Conclusion:}

A range of laboratory diagnostic methods has been developed to support patient management and disease control. The choice of diagnostic method depends on the purpose for which the testing is done (e.g. clinical diagnosis, epidemiological survey, and vaccine development), the type of laboratory facilities and technical expertise available, costs, and the time of sample collection. In general, tests with high sensitivity and specificity require more complex technologies and technical expertise, while rapid tests may compromise sensitivity and specificity for the ease of performance and speed. New diagnostic methods continue to be innovated, such as micro fluidics, paper-based diagnostics, chip-based systems, micro and nanofabrication technologies, deep sequencing, among others. Despite advances in diagnostics for flaviviral infections, there is a critical need for more sensitive, specific, easy to use and affordable tests for point of care (POC) diagnosis, multiplex virologic and serologic assays to differentiate co-circulating significance (e.g, Dengue, Chikungunya, Zika and Yellow fever) and methods for viral quantification and genomic characterization.

\section{References}

1. Coyne CB, Lazear HM. Zika virus reigniting the TORCH. Nat Rev Microbiol 2016; 14(11):707-16. https:// doi.org/10.1038/nrmicro.2016.125.PMid:27573577

2. Shukla S, Mayer SV, Tesh RB, Vasilakis N. The emergence of arthropod-borne viral diseases: A global prospective on dengue, chikungunya and zika fevers. Acta Trop 2017; 166:155-63. https://doi.org/10.1016/ j.actatropica.2016.11.020.PMid:27876643 PMCid: PMC5203945

3. Dengue strikes early. Situation indicates bigger outbreak in Dhaka. Available at URL: https:// www.thedailystar.net/frontpage/dengue-strikes-early1255999 [Retrieved 20 October, 2018].

4. Dhaka at risk of dengue outbreak. Available at URL: https://www.dhakatribune.com/bangladesh/dhaka/ 2018/07/31/dhaka-at-risk-of-dengue-outbreak. [Retrieved 20 October, 2018]

5. Hossain MS, Hasan MM, Islam MS, Islam S, Mozaffor M, Khan MA, Ahmed N, Akhtar W, Chowdhury S, Arafat SY, Khaleque MA. Chikungunya outbreak (2017) in
Bangladesh: Clinical prof.ile, economic impact and quality of life during the acute phase of the disease. PLoS Neglect Trop Dis 2018; 12(6):e0006561.https:// doi.org/10.1371/journal.pntd.0006561. PMid: 29874242 PMCid:PMC6025877

6. Institute of EpidemiologyDisease Control and Research, Chikungunya News Letter. September 7, 2017; Available at URL: http:/ / www.iedcr.gov.bd/index.php/ chikungunya/chikungunya-newsletter [Retrieved 19 October, 2018]

7. Muraduzzaman AK, Sultana S, Shirin T, Khatun S, Islam M, Rahman M. Introduction of Zika virus in Bangladesh: an impending public health threat. Asian Pac J Trop Dis 2017; 10(9):925-28. https://doi.org/ 10.1016/j.apjtm.2017.08.015.PMid:29080624

8. Hong SY, Chung SH, Kim M. Rapid detection strategies for the global threat of Zika virus: current state, new hypotheses, and limitations. Front in microbiol 2016; 7:1685-00. https://doi.org/10.3389/fmicb.2016. 01685

9. Serological Diagnosis of Zika, Dengue and Chikungunya Virus Infections. 28 Apr 2016; Available at URL: http:/ /www.selectscience.net/product-news/serologicaldiagnosis-of-zika,-dengue-and-chikungunya-virus infections / ?artID=40839 [Retrieved 5 June 2018]

10. Beltrán-Silva SL, Chacón-Hernández SS, MorenoPalacios E, Pereyra-Molina JA. Clinical and differential diagnosis: Dengue, chikungunya and Zika. Revista Médica del Hospital General de México. 2016; 81(3) 146-53.https://doi.org/10.1016/j.hgmx.2016.09.011

11. Fry SR, Meyer M, Semple MG, Simmons CP, Sekaran SD, Huang JX, McElnea C, Huang CY, Valks A, Young PR, Cooper MA. The diagnostic sensitivity of dengue rapid test assays is significantly enhanced by using a combined antigen and antibody testing approach. PLoS Neglect Trop Dis 2011; 5(6): p.e1199.https://doi.org/ 10.1371/journal.pntd.0001 199.PMid:2 1713023 PMCid:PMC3119643

12. Cao-Lormeau VM, Musso D. Emerging arboviruses in the Pacific. The Lancet. 2014; 384(9954):157172.https://doi.org/10.1016/S0140-6736(14)61977-2

13. Gubler DJ. Dengue and dengue hemorrhagic fever. Clin Microbiol Rev 1998; 11(3):480-96. https://doi.org/ 10.1128/CMR.11.3.480.PMid:9665979 PMCid: PMC88892

14. Li R, Ding J, Ding G, Fan X, He Y, Wang X, Zhang H, Ji $\mathrm{J}, \mathrm{Li}$ H. Zika virus infections, a review. Radiol Infect Dis 2017; 4(2):88-93.https://doi.org/10.1016/ j.jrid.2017.01.002

15. Calabrese LH. Emerging viral infections and arthritis: the role of the rheumatologist. Nat Rev Rheumatol 2007; 4(1):2-3.https://doi.org/10.1038/ncprheum0679. PMid:18043599

16. Dupuis-Maguiraga L, Noret M, Brun S, Le Grand R, Gras G, Roques P. Chikungunya disease: infection- 
associated markers from the acute to the chronic phase of arbovirus-induced arthralgia. PLoS Neglect Trop Dis 2012; 6(3):e1446.https://doi.org/10.1371/journal. pntd.0001446 PMid:22479654 PMCid:PMC3313943

17. Heilman JM, De Wolff J, Beards GM, Basden BJ. Dengue fever: a Wikipedia clinical review. Open Med 2014; 8(4):e105.

18. New and Innovative Approaches to Laboratory Diagnosis of Zika, Dengue and other Arboviruses. PDC _ Diagnostic Workshop _ May 2017 _ Report. Available at URL: https://www.fondation-merieux.org/en/ events/workshop-on-new-and-innovative approachesto-laboratory-diagnosis-of-zika-dengue and- otherarboviruses/ [Retrieved 5 June 2018]

19. Mardekian SK, Roberts AL. Diagnostic options and challenges for dengue and chikungunya viruses. Biomed Res Int 2015; 1-8. https://doi.org/10.1155/ 2015/834371.PMid:26509163 PMCid:PMC4609775

20. Rabe IB. Interim guidance for interpretation of Zika virus antibody test results. Morbidity and mortality weekly report. 2016; 65. Available at URL: https:// www.cdc.gov/mmwr/volumes/65/wr/mm6521e1.html [Retrieved 5 June 2018]. https://doi.org/10.15585/ mmwr.mm6521e1.PMid:27254248

21. Roehrig JT, Hombach J, Barrett AD. Guidelines for plaque-reduction neutralization testing of human antibodies to dengue viruses. Viral Immunol 2008; 21(2):123-32. https://doi.org/10.1089/ vim.2008.0007.PMid:18476771

22. Pabbaraju K, Wong S, Gill K, Fonseca K, Tipples GA, Tellier R. Simultaneous detection of Zika, Chikungunya and Dengue viruses by a multiplex real-time RT-PCR assay. J Clin Virol. 2016; 83: 66-71. https://doi.org/ 10.1016/j.jcv.2016.09.001.PMid:27614319

23. World Health Organization, Dengue: Guidelines for Diagnosis, Treatment, Prevention and Control: New Edition, World Health Organization, Geneva, Switzerland, 2009. Available at URL: htts:// www.ncbi.nlm.nih.gov/books / NBK143157/pdf/ Bookshelf_NBK143157.pdf [Retrieved 7 June 2018]

24. Centers for disease control and prevention. Laboratory Guidance and Diagnostic Testing. Available at URL: https: / / www.cdc.gov/dengue/clinicallab/ laboratory.html. [Retrieved 7 June 2018]

25. Dash M, Mohanty I, Padhi S. Laboratory diagnosis of chikungunya virus: do we really need it?. Indian J Med Sci 2011; 65(3): 83-91.https://doi.org/10.4103/00195359.104781.PMid:23250288

26. Tang KF, Ooi EE. Diagnosis of dengue: an update. Expert Rev Anti Infect Ther 2012; 10(8): 895-907.https:/ /doi.org/10.1586/eri.12.76.PMid:23030329

27. Himmelsbach K, Hildt E. Identification of various cell culture models for the study of Zika virus. World J Virol 2018; 7(1):10-23.https://doi.org/10.5501/ wjv.v7.i1.10.PMid:29468137 PMCid:PMC5807893
28. Klungthong C, Gibbons RV, Thaisomboonsuk B, Nisalak A, Kalayanarooj S, Thirawuth V,Nutkumhang N, Mammen MP, Jarman RG. Dengue virus detection using whole blood for reverse transcriptase PCR and virus isolation. J Clin Microbiol 2007; 45(8): 248085.https: / / doi.org/10.1128/JCM.0030507.PMid:17522268 PMCid:PMC1951229

29. Parashar D, Paingankar MS, Sudeep AB, More A, Shinde SB, Arankalle VA. Assessment of qPCR, nested RT-PCR and ELISA techniques in diagnosis of Chikungunya. Curr Sci 2014; 20

30. Centers for Disease Control and Prevention. Interim guidance for Zika virus testing of urine-_-United States. Morbidity and mortality weekly report.2016; 65. Available at URL: https://www.cdc.gov/mmwr/ volumes/65/wr/mm6518e1.html. [Retrieved 8 June 2018]

31. Faye O, Faye O, Diallo D, Diallo M, Weidmann M. Quantitative real-time PCR detection of Zika virus and evaluation with field-caught mosquitoes. J Virol 2013; 10(1):311-18. https://doi.org/10.1186/1743-422X-10311.PMid:24148652 PMCid:PMC4016539

32. Oduyebo T. Update: interim guidelines for health care providers caring for pregnant women and women of reproductive age with possible Zika virus exposureUnited States, 2016. Morbidity and mortality weekly report. 2016; 65. Available at URL: https:// www.cdc.gov/mmwr/volumes/65/wr/mm6505e2.htm [Retrieved 8 June 2018]

33. Chan JF, Choi GK, Yip CC, Cheng VC, Yuen KY. Zika fever and congenital Zika syndrome: an unexpected emerging arboviral disease. J Infect 2016; 72(5): 50724. https://doi.org/10.1016/j.jinf.2016.02.011. PMid:26940504

34. Dutra NR, de Paula MB, de Oliveira MD, de Oliveira LL, De Paula SO. The laboratorial diagnosis of dengue: applications and implications. J Glob Infect Dis 2009; 1(1): 38-44. https://doi.org/10.4103/0974777X.52980.PMid:20300385 PMCid:PMC2840934

35. Dahiya S, Kumar M, Singh B, Dabas R, Kumar S. Chikungunya: A Remerging Arboviral Dis 2015; 6(2):144-56.

36. Pfeffer M, Linssen B, Parke MD, Kinney RM. Specific detection of chikungunya virus using a RT PCR/nested PCR combination. J Vet Med B Infect Dis Vet Public Health 2002; 49: 49-54. https://doi.org/10.1046/ j.1439-0450.2002.00535.x.PMid:11911593

37. Hasebe F, Parquet MC, Pandey BD, Mathenge EG, Morita K, Balasubramaniam V, Saat Z, Yusop A, Sinniah $\mathrm{M}$, Natkunam S, Igarashi A. Combined detection and genotyping of Chikungunya virus by a specific reverse transcription polymerase chain reaction. J Med Virol 2002; 67(3): 370-74. https://doi.org/10.1002/ jmv.10085.PMid:12116030 
38. Notomi, T., Mori, Y., Tomita, N.\& Kanda, H. Loopmediated isothermal amplification (LAMP): principle, features, and future prospects. J Microbiol 2015; 53, 1-5. https: / / doi.org/10.1007/s12275-015-46569.PMid:25557475

39. Teoh BT, Sam SS, Tan KK, Johari J, Danlami MB, Hooi PS, Md-Esa R, AbuBakar S. Detection of dengue viruses using reverse transcription-loop-mediated isothermal amplification. BMC Infectious Dis 2013; 13(1): 38796.https://doi.org/10.1186/1471-2334-13387.PMid:23964963 PMCid:PMC3846474

40. Parida MM, Santhosh SR, Dash PK, Tripathi NK, Lakshmi V, Mamidi N, Shrivastva A, Gupta N, Saxena P, Babu JP, Rao PL. Rapid and real-time detection of Chikungunya virus by reverse transcription loopmediated isothermal amplification assay. J Clinical Microbiol 2007; 45(2): 351-357.https://doi.org/ 10.1128 / JCM.01734-06.PMid: 17135444 PMCid:PMC1829040

41. Song J, Mauk MG, Hackett BA, Cherry S, Bau HH, Liu C. Instrument-free point-of-care molecular detection of Zika virus. Anal Chem 2016; 88(14):7289-94. https:// doi.org/10.1021/acs.analchem.6b01632. PMid:27306491 PMCid:PMC4955015

42. Centers for Disease Control and Prevention 2016. Diagnostic Test for Zika Virus-Trioplex Real Time RTPCR Assay Instructions. Available at URL: https:// www.cdc.gov/zika/pdfs/trioplex-real-time-rt-pcrassay-instructions-for-use.pdf. [Retrieved 10 July 2018]

43. Santiago GA, Vázquez J, Courtney S, Matías KY, Andersen LE, Colón C, Butler AE, Roulo R, Bowzard J, Villanueva JM, Muñoz-Jordan JL. Performance of the Trioplex real-time RT-PCR assay for detection of Zika, dengue, and chikungunya viruses. Nat Commun 2018; 9(1):1391-01. https://doi.org/10.1038/s41467-01803772-1.PMid:29643334 PMCid:PMC5895813

44. Caglioti C, Lalle E, Castilletti C, Carletti F, Capobianchi MR, Bordi L. Chikungunya virus infection: an overview. New Microbiol 2013; 36(3): 211-17.

45. Sudeep AB, Parashar D. Chikungunya: an overview. J Biosci Med 2008; 33(4): 443-49. https://doi.org/ $10.1007 / \mathrm{s} 12038-008-0063-2$

46. Kumar SM, Sheethal S. Comparison of NS-1 Antigen Detection by ICT and ELISA for Evaluating Acute Dengue. Int J Curr Microbiol App Sci 2018;7(2):365260. https://doi.org/10.20546/ijcmas.2018.702.434

47. Chakraverti TK, Sreepuram ND. Comparision of diagnostic efficacy of NS1 antigen based immunochromatographic test with immuno-sorbent assay and its role in detection of early dengue infection. J Med Dent Sci 2012; 1(6):1066-70.https://doi.org/ $10.14260 /$ jemds $/ 175$

48. Chen LH, Wilson ME. Dengue and chikungunya infections in travelers. Curr Opin Infect Dis 2010; 23(5): 438-44.https: / / doi.org/10.1097/QCO.0b013e 32833c1d16.PMid:20581669
49. Bosch I, de Puig H, Hiley M, Carré-Camps M, PerdomoCelis F, Narváez CF, Salgado DM, Senthoor D, O'grady M, Phillips E, Durbin A. Rapid antigen tests for dengue virus serotypes and Zika virus in patient serum. Sci Trans1 Med 2017; 9(409):e1589.

50. Chen LH, Wilson ME. Dengue and chikungunya in travelers: recent updates. Curr Opin Infect Dis 2012; 25(5): $\quad$ 523-529.https://doi.org/10.1097/ QCO.0b013e328356ffd5.PMid:22825287

51. Steinhagen K, Probst C, Radzimski C, SchmidtChanasit J, Emmerich P, van Esbroeck M, Schinkel J, Grobusch MP, Goorhuis A, Warnecke JM, Lattwein E. Serodiagnosis of Zika virus (ZIKV) infections by a novel NS1-based ELISA devoid of cross-reactivity with dengue virus antibodies: a multicohort study of assay performance, 2015 to 2016. Euro surveill 2016; 21(50): 1-16. https://doi.org/10.2807/1560-7917.ES.2016. 21.50.30426.PMid:28006649 PMCid:PMC5291135

52. World Health Organization, Special Programme for Research, Training in Tropical Diseases. Dengue guidelines for diagnosis, treatment, prevention and control: new edition. Geneva: WHO; 2009. Available at URL:www.who.int/tdr/publications / documents / dengue-diagnosis.pdf. [Retrieved 10 July 2018]

53. Burdino E, Calleri G, Caramello P, Ghisetti V. Unmet needs for a rapid diagnosis of chikungunya virus infection. Emerging infectious diseases. 2016; 22(10): 1837. Available at URL: https:/ / wwwnc.cdc.gov/ eid/article/22/10/15-1784_article [Retrieved 10 July 2018] https://doi.org/10.3201/eid2210.151784. PMid:27347706 PMCid:PMC5038423

54. Kim YH, Lee J, Kim YE, Chong CK, Pinchemel Y, Reisdörfer F, Coelho JB, Dias RF, Bae PK, Gusmão ZP, Ahn HJ. Development of a Rapid Diagnostic Test Kit to Detect IgG/IgM Antibody against Zika Virus Using Monoclonal Antibodies to the Envelope and Nonstructural Protein 1 of the Virus. Korean J Parasitol 2018; 56(1): 61-70.https://doi.org/10.3347/ kjp.2018.56.1.61 https://doi.org/10.3347/ kjp.2013.51.1.61

55. World Health Organization, Regional Office for SouthEast Asia. Comprehensive guidelines for prevention and control of dengue and dengue hemorrhagic fever: revised and expanded edition. New Delhi: WHO; 2011. Available at: http:/ / www.searo.who. int / entity/ vector borne tropical diseases/documents/SEAROTPS60/en [Retrieved 10 July 2018]

56. Lineamientos para la vigilancia epidemiológica de Dengue por laboratorio. México: Secretaría de Salud, INDRE; 2015. Available at URL: http:// www.indre.salud.gob.mx/opencms/opencms/sites / indre/descargas/pdf/Lineamientos/lineamiento para la vigilancia de dengue.pdf [Retrieved 10 July 2018]

57. Johnson BW, Russell BJ, Goodman CH. Laboratory diagnosis of chikungunya virus infections and 
commercial sources for diagnostic assays. J Infect Dis 2016; 214(suppl_5):471-74. https://doi.org/10.1093/ infdis/jiw274.PMid:27920176 PMCid:PMC5657184

58. Centers for Disease Control and Prevention. Diagnostic Tests for Zika Virus. Available at URL: https:// www.cdc.gov/zika/hc-providers/types-of-tests.html. [Retrieved 10 July 2018]

59. Falconar AK, de Plata E, Romero-Vivas CM. Altered enzyme-linked immunosorbent assay immunoglobulin M (IgM)/IgG optical density ratios can correctly classify all primary or secondary dengue virus infections 1 day after the onset of symptoms, when all of the viruses can be isolated. Clin Vaccine Immunol 2006, 13:104451.https://doi.org/10.1128/CVI.00105-06.PMid: 16960117 PMCid:PMC1563575

60. Vázquez S, Cabezas S, Pérez AB, Pupo M, Ruiz D, Calzada N, Bernardo L, Castro O, González D, Serrano $\mathrm{T}$, Sanchez A. Kinetics of antibodies in sera, saliva, and urine samples from adult patients with primary or secondary dengue 3 virus infections. Int $\mathrm{J}$ Infect Dis. 2007; 11(3): 256-62. https://doi.org/10.1016/ j.ijid.2006.05.005.PMid:16914345

61. Nawa M. Immunoglobulin A antibody responses in dengue patients: a useful marker for serodiagnosis of dengue virus infection. Clin Vaccine Immunol 2005, 12:1235-37. https://doi.org/10.1128/CDLI.12.10. 1235-1237.2005.PMid:16210489 PMCid:PMC1247829

62. Kam YW, Pok KY, Eng KE, Tan LK, Kaur S, Lee WW et al. Sero-prevalence and cross-reactivity of chikungunya virus specific anti-E2EP3 antibodies in arbovirusinfected patients. PLoS Neglect Trop Dis 2015; 9(1):e3445.https://doi.org/10.1371/journal.pntd. 0003445.PMid:25568956 PMCid:PMC4287563
63. Mardekian SK, Roberts AL. Diagnostic options and challenges for dengue and chikungunya viruses. BioMed Res Int. 2015; 2015:1-8.https://doi.org/ 10.1155/2015/834371 PMid:26509163 PMCid:PMC 4609775

64. Singhal N, Kumar M, Kanaujia PK, Virdi JS. MALDITOF mass spectrometry: an emerging technology for microbial identification and diagnosis. Front in microbiol 2015; 6:791-07. https://doi.org/10.3389/ fmicb.2015.00791.PMid:26300860 PMCid: PMC4525378

65. Chen WH, Hsu IH, Sun YC, Wang YK, Wu TK. Immunocapture couples with matrix-assisted laser desorption/ionization time-of-flight mass spectrometry for rapid detection of type 1 dengue virus. J Chromatogr 2013; 1288:21-27.https://doi.org/10.1016/ j.chroma.2013.02.030 https://doi.org/10.1016/ j.chroma.2013.08.062.PMid:24011505

66. Centers for Disease Control and Prevention 2016. Revised diagnostic testing for Zika, chikungunya, and dengue viruses in US Public Health Laboratories. Available at URL: https://www.cdc.gov/zika/pdfs/ denvchikvzikv-testing-algorithm.pdf. [Retrieved 15 July 2018]

67. Banerjee A, Paul UK, Bandyopadhyay A. Diagnosis of dengue fever: roles of different laboratory test methods. International Journal of Advances in Medicine. 2018 Mar 21;5(2):395-9. https://doi.org/10.18203/23493933.ijam20181076

68. Sathish N, Vijayakumar TS, Abraham P, Sridharan G. Dengue Fever: Its Laboratory Diagnosis, with Special Emphasis on IgM Detection. Dengue Bulletin - Vol 27, 2003 116-125 